\title{
Germination strategies of annual and short-lived perennial species in the Arabian Desert
}

\author{
Arvind BHATT ${ }^{1}$, David J GALLACHER ${ }^{2 *}$, Paulo R M SOUZA-FILHO ${ }^{3}$ \\ ${ }^{1}$ Lushan Botanical Garden, Chinese Academy of Sciences, Jiujiang 332900, China; \\ ${ }^{2}$ School of Life and Environmental Sciences, The University of Sydney, Narrabri NSW 2390, Australia; \\ ${ }^{3}$ Multidisciplinary Center of Barra, Federal University of Western Bahia, Barra 47100-000, Brazil
}

\begin{abstract}
Germination timing is highly regulated in short-lived plant species since it strongly influences recruitment success of vegetation. In deserts, the spatiotemporal distribution of plant-available water is highly episodic and unpredictable, making winter months more favorable for seed germination when other abiotic conditions co-occur. We hypothesized that changes in photoperiod and thermoperiod would impact germination more in seeds that had undergone in situ storage. We assessed 21 annual and short-lived perennial species in the Arabian Desert to find (1) if seeds were dormant at maturity, (2) if in situ seed storage increased germination percentage compared with no storage, (3) if photoperiod and thermoperiod germination requirements were influenced by in situ storage, and (4) if a phylogenetic association in seed germination could be observed. Seeds of each species collected in early 2017 were divided into two batches. One was tested for germination within one week (fresh seeds). The other was stored in situ at the maternal location (stored seeds) until October 2017 and tested for seed germination in the first week of November. Seed germination was conducted in incubators at two thermoperiods $\left(15^{\circ} \mathrm{C} / 20^{\circ} \mathrm{C}\right.$ and $\left.20^{\circ} \mathrm{C} / 30^{\circ} \mathrm{C} ; 12 \mathrm{~h} / 12 \mathrm{~h}\right)$, and two photoperiods (12 and $0 \mathrm{~h}$ light per day). Results indicated that seed germination percentages of 13 species were significantly enhanced by in situ storage. A thermoperiod response was exhibited by stored, but not fresh seeds. Light exposure increased germination of fresh seeds but had only a minimal effect on stored seeds. Germination traits exhibited no phylogenetic correlation. This result indicated that selection pressure for germination strategy was stronger than that for taxonomic traits of these desert species.
\end{abstract}

Keywords: desert species; dormancy; germination; light; temperature; phylogeny

Citation: Arvind BHATT, David J GALLACHER, Paulo R M SOUZA-FILHO. 2020. Germination strategies of annual and short-lived perennial species in the Arabian Desert. Journal of Arid Land, 12(6): 1071-1082. https://doi.org/10.1007/s40333-020-0023-8

\section{Introduction}

Seed dormancy at time of maturation is common in plant species generally. Dormancy enables the delay of germination until conditions are more suitable for recruitment success (Clauss and Venable, 2000; Liu et al., 2013). Arabian Desert has harsh environments characterized by high summer temperatures (May to October) and extremely low and unpredictable precipitation ( $<200$ mm/a) occurring mostly in winter (November to April; Böer, 1997; Harel et al., 2011; Almazroui et al., 2012). Spatiotemporal distribution of precipitation in deserts is highly episodic and unpredictable (Terradas, 1991). Plant growth in deserts occurs in winter when moisture is

\footnotetext{
*Corresponding author: David J GALLACHER (E-mail: d.gallacher@sydney.edu.au)

Received 2020-03-09; revised 2020-07-27; accepted 2020-08-10

(C) Xinjiang Institute of Ecology and Geography, Chinese Academy of Sciences, Science Press and Springer-Verlag GmbH Germany, part of Springer Nature 2020
} 
available, producing seeds before the onset of summer (Petrie, 2007). Seeds remain dormant until the following winter when temperature drops, and the chance of multiple precipitation events is greater in winter (Bhatt and Pérez-García, 2016).

Seed dormancy occurs in more than $80 \%$ of desert species worldwide (Baskin and Baskin, 2014), but varies in both mechanism and degree, hereafter referred to as germination strategy. Evolutionary pressure on germination strategy acts to maximize recruitment success for current environmental conditions (Finch-Savage and Leubner-Metzger, 2006; Carta et al., 2014). Climate is the primary environmental factor to influence germination strategy (Fenner and Thompson, 2005). Climate includes seasonal and daily changes in temperature and precipitation, affecting both the quantity and reliability of plant-available water within a season. Water is the main limiter of seedling survival in the Arabian Desert since annual precipitation is low and highly variable (El-Keblawy, 2017). The important strategy of most plant species in the Arabian Desert is to germinate after precipitation in early- to mid-winter for maintaining the establishment of community.

Germination timing is highly responsive to environmental conditions (Donohue, 2002). Proper timing reduces seedling mortality and correlates with seedling growth potential (Evans and Cabin, 1995). Many species can adjust seasonal timing of germination by recognizing other environmental cues (Gutterman, 1972; Donohue et al., 2010; Barua et al., 2012). For example, dispersed seeds in desert are often exposed to a microenvironment of extreme diurnal temperature variation at the soil surface, which might trigger dormancy alleviation pathways (Baskin and Baskin, 1988; Jordan and Haferkamp, 1989). Germination studies conducted ex situ can easily miss these microenvironmental conditions, resulting in an inaccurate understanding of dormancy alleviation (Mira et al., 2011). In situ germination studies are more difficult, but sometimes necessary to understand the regulation of seed germination in natural settings.

Temperature and light play significant roles in the germination strategy of many desert species (El-Keblawy et al., 2011; Menon et al., 2014; Bhatt and Pérez-García, 2016; Bhatt et al., 2016a, b, c; Bhatt and Santo, 2017). The relationship between light exposure and germination in a species can be positive, negative or neutral, and indicates a preference against, for, or ambivalence toward seed burial (Baskin and Baskin, 2014). Seeds can be covered by leaf litter, transported underground by granivores, or buried by shifting sand. A preference for germinating in darkness indicates the species is adapted to one of these events (Fenner and Thompson, 2005).

Germination strategy could exhibit phylogenetic trends, in which closely related species exhibit similar germination behavior regardless of climate (Burns and Strauss, 2011). Alternatively, a distinctive climate could homogenize germination strategies (Wang et al., 2009). These countering selection pressures could leave weak but significant phylogenetic traces among related species (Seglias et al., 2018). The responses of seed germination to thermoperiod, photoperiod and storage are strongly heritable, and therefore become good indicators of genotypic preservation among climates (Liu et al., 2018; Seglias et al., 2018; Tudela-Isanta et al., 2018).

Duration of physiological dormancy can be influenced by seed storage conditions. Climatic regulation to reduce dormancy during storage is termed after-ripening (Holdsworth et al., 2008), and is important for efficient artificial propagation of many arid zone species (Commander et al., 2009; Baskin and Baskin, 2014; Erickson, 2015; Bhatt and Pérez-García, 2016; Zhang et al., 2016). Seeds stored ex situ at room temperature can maintain dormancy from several months to a year (Schütz et al., 2002; Baker et al., 2005). We hypothesized that seeds stored in situ would exhibit dormancy release, and that a change in photoperiod and thermoperiod would have greater impact on germination, compared with unstored seeds. We examined for each species: (1) if seeds were dormant at maturity; (2) if in situ seed storage alleviates dormancy; (3) if photoperiod and thermoperiod germination requirements were influenced by in situ storage; and (4) if germination strategy could be linked to phylogeny.

\section{Materials and methods}

\subsection{Seed collection}

We selected 21 species (14 annual and 7 perennial) in the Arabian Desert on the basis of being 
relatively common, and for having ecological or economic importance (Table 1). Most are preferred fodder species for sheep, goats and camels (Omar et al., 2007; Norton et al., 2009). Seeds from selected species were collected between March and June 2017 from coast, inland and peri-urban Kuwait at the time of their natural dispersal (Table 1). Seeds were collected from at least 25 plants along a 150-180-m transect through a population, leaving a minimum of $2 \mathrm{~m}$ between plants.

Table 1 Species collected, and date and location of seeds collection

\begin{tabular}{|c|c|c|c|c|c|}
\hline Family/species & Life form & Mohth & Location & Latitude & Longitude \\
\hline $\begin{array}{l}\text { Amaranthaceae } \\
\text { Suaeda vermiculata Forssk. Ex J.F.Gmel. } \\
\text { Asteraceae }\end{array}$ & Perennial & April & Coast & $28^{\circ} 54^{\prime} 19^{\prime \prime} \mathrm{N}$ & $48^{\circ} 13^{\prime} 22^{\prime \prime} \mathrm{E}$ \\
\hline $\begin{array}{l}\text { Calendula arvensis L. } \\
\text { Boraginaceae }\end{array}$ & Annual & April & Peri-urban & $29^{\circ} 09^{\prime} 47^{\prime \prime} \mathrm{N}$ & $47^{\circ} 41^{\prime} 28^{\prime \prime} \mathrm{E}$ \\
\hline $\begin{array}{c}\text { Moltkiopsis ciliata (Forsk.) I. M. Johnst. } \\
\text { Brassicaceae }\end{array}$ & Perennial & May & Peri-urban & $29^{\circ} 09^{\prime} 31^{\prime \prime} \mathrm{N}$ & $47^{\circ} 38^{\prime} 09^{\prime \prime} \mathrm{E}$ \\
\hline Horwoodia dicksoniae Turrill & Annual & May & Peri-urban & $29^{\circ} 09^{\prime} 29^{\prime \prime} \mathrm{N}$ & $47^{\circ} 38^{\prime} 11^{\prime \prime} \mathrm{E}$ \\
\hline Savignya parviflora (Delile) Webb & Annual & March & Peri-urban & $29^{\circ} 09^{\prime} 46^{\prime \prime} \mathrm{N}$ & $47^{\circ} 41^{\prime} 28^{\prime \prime} \mathrm{E}$ \\
\hline $\begin{array}{l}\text { Brassica tournefortii Gouan } \\
\text { Caryophyllaceae }\end{array}$ & Annual & April & Peri-urban & $29^{\circ} 09^{\prime} 41^{\prime \prime} \mathrm{N}$ & $47^{\circ} 41^{\prime} 35^{\prime \prime} \mathrm{E}$ \\
\hline Gypsophila capillaris (Forsk.) C. Chr. & Annual & May & Peri-urban & $29^{\circ} 09^{\prime} 44^{\prime \prime} \mathrm{N}$ & $47^{\circ} 41^{\prime} 26^{\prime \prime} \mathrm{E}$ \\
\hline Silene arabica Boiss. & Annual & March & Peri-urban & $29^{\circ} 09^{\prime} 47^{\prime \prime} \mathrm{N}$ & $47^{\circ} 41^{\prime} 28^{\prime \prime} \mathrm{E}$ \\
\hline $\begin{array}{l}\text { Silene villosa Forsk. } \\
\text { Cistaceae }\end{array}$ & Annual & May & Peri-urban & $29^{\circ} 09^{\prime} 35^{\prime \prime} \mathrm{N}$ & $47^{\circ} 41^{\prime} 32^{\prime \prime} \mathrm{E}$ \\
\hline $\begin{array}{c}\text { Helianthemum lippii (L.) Dum. Courset } \\
\text { Liliaceae }\end{array}$ & Perennial & April & Peri-urban & $29^{\circ} 09^{\prime} 51^{\prime \prime} \mathrm{N}$ & $47^{\circ} 41^{\prime} 43^{\prime \prime} \mathrm{E}$ \\
\hline $\begin{array}{c}\text { Asphodelus tenuifolius Cav. } \\
\text { Malvaceae }\end{array}$ & Annual & March & Peri-urban & $29^{\circ} 09^{\prime} 45^{\prime \prime} \mathrm{N}$ & $47^{\circ} 41^{\prime} 34^{\prime \prime} \mathrm{E}$ \\
\hline $\begin{array}{l}\text { Malva parviflora } \mathrm{L} . \\
\text { Poaceae }\end{array}$ & Annual & May & Peri-urban & $29^{\circ} 09^{\prime} 34^{\prime \prime} \mathrm{N}$ & $47^{\circ} 41^{\prime} 34^{\prime \prime} \mathrm{E}$ \\
\hline Eragrostis curvula (Schrad.) Nees & Perennial & May & Inland & $29^{\circ} 09^{\prime} 26^{\prime \prime} \mathrm{N}$ & $47^{\circ} 09^{\prime} 26^{\prime \prime} \mathrm{E}$ \\
\hline Panicum acuminatum Sw. & Perennial & May & Peri-urban & $29^{\circ} 09^{\prime} 46^{\prime \prime} \mathrm{N}$ & $47^{\circ} 36^{\prime} 28^{\prime \prime} \mathrm{E}$ \\
\hline Polypogon monspeliensis (L.) Desf. & Annual & May & Peri-urban & $29^{\circ} 09^{\prime} 46^{\prime \prime} \mathrm{N}$ & $47^{\circ} 36^{\prime} 37^{\prime \prime} \mathrm{E}$ \\
\hline Digitaria sanguinalis (L.) Scop. & Annual & May & Peri-urban & $29^{\circ} 09^{\prime} 51^{\prime \prime} \mathrm{N}$ & $47^{\circ} 41^{\prime} 32^{\prime \prime} \mathrm{E}$ \\
\hline $\begin{array}{c}\text { Eragrostis barrelieri Daveau } \\
\text { Polygonaceae }\end{array}$ & Annual & May & Coast & $28^{\circ} 56^{\prime} 23^{\prime \prime} \mathrm{N}$ & $48^{\circ} 11^{\prime} 35^{\prime \prime} \mathrm{E}$ \\
\hline $\begin{array}{c}\text { Rumex vesicarius L. } \\
\text { Resedaceae }\end{array}$ & Annual & May & Peri-urban & $29^{\circ} 09^{\prime} 50^{\prime \prime} \mathrm{N}$ & $47^{\circ} 41^{\prime} 32^{\prime \prime} \mathrm{E}$ \\
\hline $\begin{array}{l}\text { Reseda arabica Boiss. } \\
\text { Rutaceae }\end{array}$ & Annual & March & Peri-urban & $29^{\circ} 09^{\prime} 46^{\prime \prime} \mathrm{N}$ & $47^{\circ} 41^{\prime} 28^{\prime \prime} \mathrm{E}$ \\
\hline $\begin{array}{l}\text { Haplophyllum tuberculatum (Forsk.) Ad. Juss. } \\
\text { Zygophyllaceae }\end{array}$ & Perennial & May & Coast & $28^{\circ} 52^{\prime} 31^{\prime \prime} \mathrm{N}$ & $48^{\circ} 17^{\prime} 30^{\prime \prime} \mathrm{E}$ \\
\hline Peganum harmala L. & Perennial & June & Peri-urban & $29^{\circ} 09^{\prime} 50^{\prime \prime} \mathrm{N}$ & $47^{\circ} 41^{\prime} 05^{\prime \prime} \mathrm{E}$ \\
\hline
\end{tabular}

Freshly collected seeds were cleaned and divided into two batches. One was tested for seed germination within one week (fresh seeds). The other was stored outside (in situ) in a nylon bag (mesh size $0.2 \mathrm{~mm}$ ) and placed on the soil surface until October 2017 (stored seeds). Whenever 
rain was forecast, seeds of the natural storage were removed and returned back shortly after improvement of the weather. In the first week of November (at the time of onset of rain in Kuwait), the stored seeds were retrieved for each species and tested for germination again. The climate in Kuwait is characterized by a long, dry and hot summer with daytime temperatures occasionally exceeding $50^{\circ} \mathrm{C}$, and cooler winters with extreme lows below $4^{\circ} \mathrm{C}$. Precipitation is scarce, with less than $114 \mathrm{~mm}$ annually and mostly occurring during winter between October and March (Omar et al., 2007).

\subsection{Seed germination}

Seed germination was conducted in incubators at two temperatures $\left(15^{\circ} \mathrm{C} / 20^{\circ} \mathrm{C}\right.$ and $20^{\circ} \mathrm{C} / 30^{\circ} \mathrm{C}$; $12 \mathrm{~h} / 12 \mathrm{~h}$ ) and two light regimes (12 and $0 \mathrm{~h}$ light per day) that termed light and dark treatments. Light was provided by a 50-W white fluorescent lamp with the light period coinciding with the high temperature. Germination was conducted in 9-cm tight-fitting Petri dishes containing one disk of Whatman No. 1 filter paper, wetted with $10 \mathrm{~mL}$ of distilled water using 4 replicates of 25 seeds each. In dark treatment, Petri dishes were wrapped in aluminum foil. Seed germination was defined as emergence of the radicle ( $\geq 2 \mathrm{~mm}$ ) and was assessed daily for light-exposed seeds. Seeds incubated in continuous darkness were counted after $26 \mathrm{~d}$ when experiments were terminated. At termination, viability of non-germinated seeds was tested to identify damage from treatments. This analysis was performed by seed dissection and visual determination of the embryo status using a binocular microscope, in which white and turgid indicated alive and brownish indicated dead.

\subsection{Statistical analysis}

All analyses were performed with $\mathrm{R}$ software. We analyzed final germination using a generalized linear mixed model, and the germination rate using a time-to-event analysis (also known as survival analysis). These analyses were selected for their power to account for random effects (Onofri et al., 2010; Sileshi, 2012). The model was binomial error distributed with logit link function (lme4 package) (Bates et al., 2014) with species as a random effect. The model selection used the Akaike Information Criterion (AIC), over dispersal and normality of the residuals (Zuur et al., 2009). We tested the fixed effects of storage (in situ stored seeds vs. unstored seeds), thermal environment $\left(15^{\circ} \mathrm{C} / 20^{\circ} \mathrm{C}\right.$ and $\left.20^{\circ} \mathrm{C} / 30^{\circ} \mathrm{C}\right)$ and light $(12$ and $0 \mathrm{~h}$ per day) on seed germination and their interaction. The interaction of thermal and light was then excluded from the model as it was not significant. For the random component of the full model, species were nested to the replicate Petri dishes as components of random intercept and the storage effect slopes. The model coefficients $(\beta)$ were analyzed by multiple pairwise Z-test comparison via least-square means (multcomp package (Hothorn et al., 2008) and lsmeans package (Lenth, 2016)). The model was run with all species included, and then for each species separately.

We built the germination behavior matrix using the following species' germination:

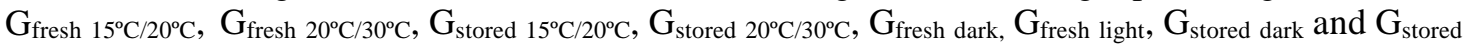
light, coefficients from the random intercept (species) and random slopes of the full model (storage). A dissimilarity matrix using Euclidian distance (vegan package; Oksanen et al., 2019) was used to make a hierarchical clustering analysis to group species into seed germination behavior and a principal component analysis (PCA) to summarize them into scores.

Time-to-event analysis was used for germination rate modelling (survival package; Therneau and Grambsch, 2000; Onofri et al., 2010) for the species P. acuminatum, P. hamala and S. vermiculata that did not exhibit dormancy. Germination times (d) of individual seeds were used to calculate the probability that one seed may germinate after a specific time $t$ once the assay began. Parametric accelerated failure/time modelling was run with log-logistic distribution, the best AIC score and the most appropriate in relation to the non-parametric Kaplan-Meyer estimator. This analysis was done to detect variation in seed germination behavior of low dormancy species. The model included effects of storage, thermal response, species and the interaction of treatments as fixed factors, with all variables being significance tested (Onofri et al., 2010; Délye et al., 2013). When ready, the final model was Z-tested for factor effects on the germination curve coefficients 
via multiple comparison with Bonferroni $P$-value adjustment.

\subsection{Phylogenetic analysis}

For detection of a phylogenetic trace on seed germination behavior scored from the PCA (94.77\%), we built a phylogenetic tree with the zanne2014 stored tree (Webb and Donoghue, 2005; Zanne et al., 2014). We evaluated species' behavior via Abouheif's $C_{\text {mean }}$ to detect phylogenetic autocorrelation in the germination behavior traits (adephylo package; Jombart and Dray, 2008) and Pangel's $\lambda$ to detect the phylogenetic signal based on the Brownian motion evolution model (phytools package; Ravell, 2012). Both methods were evaluated via Monte-Carlo simulation tests within 1000 repetitions.

\section{Results}

Most species exhibited dormancy alleviation in response to in situ storage (Tables 2 and 3), though the extent of the effect varied. Exceptions were A. tenuifolius and $R$. arabica that exhibited deep dormancy, and M. parviflora that exhibited no dormancy. Dormancy was strongly alleviated ( $>10 \%$ increase in seed germination) in 12 species and weakly alleviated $(<10 \%)$ in 5 species (Table 3). S. parviflora, P. harmala and S. vermiculata exhibited a low alleviation due to the high germination of fresh seed, but the effect of storage was observed on specific thermoperiod and photoperiod.

Table 2 Coefficients of generalized linear mixed model of in situ storage, thermoperiod, photoperiod and their interactions

\begin{tabular}{ccccc}
\hline Factor & Treatment & Estimate & Standard error & $P$ \\
\hline Intercept & Fresh, dark, $15^{\circ} \mathrm{C} / 20^{\circ} \mathrm{C}$ & -6.213 & 1.129 & $<0.001$ \\
Storage & Stored & 5.305 & 0.887 & $<0.001$ \\
Thermoperiod & $20^{\circ} \mathrm{C} / 30^{\circ} \mathrm{C}, 12 \mathrm{~h} / 12 \mathrm{~h}$ & -0.064 & 0.136 & 0.638 \\
Photoperiod & $12 \mathrm{~h} \mathrm{light} \mathrm{per} \mathrm{day}$ & 0.660 & 0.137 & $<.172$ \\
Interaction & Stored $\times 20^{\circ} \mathrm{C} / 30^{\circ} \mathrm{C}$ & -0.759 & 0.001 \\
Interaction & Stored $\times$ Light & -0.430 & 0.172 & 0.013 \\
\hline
\end{tabular}

In situ stored seeds exhibited a response to thermoperiod requirement $(\beta=0.82( \pm 0.10), z=7.81$, $P<0.001)$, but fresh seeds did not $(\beta=0.06( \pm 0.14), z=0.47, P=0.64)$. In addition, both thermoperiod conditions presented a significant increase of seed germination after in situ storage, but there was also a tendency toward a higher germination at $15^{\circ} \mathrm{C} / 20^{\circ} \mathrm{C}$ than at $20^{\circ} \mathrm{C} / 30^{\circ} \mathrm{C}(\beta=$ -5.09 ( \pm 0.88$), z=-5.77, P<0.001 ; \beta=-4.33( \pm 0.88), z=-4.89, P<0.001$, respectively). As an example, stored $C$. avensis, $H$. dicksoniae, $M$. ciliata, $P$. harmala, $S$. arabica and $S$. villosa seeds presented higher germination percentages under colder than hotter temperatures (Table 3). However, for $D$. sanguinalis and $H$. tuberculatum, the hotter temperature induced a higher germination percentage.

Effect of photoperiod on germination was highly significant (Table 2). Exposure to $12 \mathrm{~h} / 12 \mathrm{~h}$ photoperiod increased germination of fresh seeds $(\beta=-0.66( \pm 0.14), z=-4.81, P<0.001)$, but had a minimal effect on stored seeds $(\beta=-0.23( \pm 0.10), z=-2.18, P=0.030)$.

Five groups of species were identified through hierarchical clustering, divided primarily on germination percentage before and after in situ storage (Fig. 1). Although Group I did not exhibit dormancy, the time of seed germination was reduced by in situ storage by an average of $6 \mathrm{~h}$ (Fig. 2; $\beta=0.28( \pm 0.14), z=2.05, P=0.04)$. Time of seed germination of this group was reduced by $34 \mathrm{~h}$ under the $15^{\circ} \mathrm{C} / 20^{\circ} \mathrm{C}$ temperature, compared with the $20^{\circ} \mathrm{C} / 30^{\circ} \mathrm{C}$ temperature $(\beta=0.53$ $( \pm 0.14), z=3.64, P<0.001)$. The phylogenetic signal was observed for PCA1 scores (seed behavior summary; Fig. 3). The species germination presented a non-significant effect from both tests 
Abouheif's $C_{\text {means }}(K=0.08, P=0.270)$ and Pangel's $\lambda\left(\lambda=6.61^{-5}, P=1.000\right)$, meaning that individual germination responses were not phylogenetically linked.

Table 3 Seed germination percentage for each species, ordered by clustered groups

\begin{tabular}{|c|c|c|c|c|c|c|c|c|}
\hline \multirow{3}{*}{$\begin{array}{l}\text { Group and } \\
\text { species }\end{array}$} & \multicolumn{4}{|c|}{ Fresh seeds (\%) } & \multicolumn{4}{|c|}{ In situ stored seeds (\%) } \\
\hline & \multicolumn{2}{|c|}{$15^{\circ} \mathrm{C} / 20^{\circ} \mathrm{C}$} & \multicolumn{2}{|c|}{$20^{\circ} \mathrm{C} / 30^{\circ} \mathrm{C}$} & \multicolumn{2}{|c|}{$15^{\circ} \mathrm{C} / 20^{\circ} \mathrm{C}$} & \multicolumn{2}{|c|}{$20^{\circ} \mathrm{C} / 30^{\circ} \mathrm{C}$} \\
\hline & 12 h light & 0 h light & 12 h light & $0 \mathrm{~h}$ light & 12 h light & 0 h light & 12 h light & $0 \mathrm{~h}$ light \\
\hline \multicolumn{9}{|l|}{ Group I } \\
\hline P. acuminatum & $89 \pm 3^{\mathrm{ab}}$ & $76 \pm 4^{b}$ & $93 \pm 2^{\mathrm{a}}$ & $83 \pm 3^{\mathrm{ab}}$ & $95 \pm 2^{\mathrm{a}}$ & $95 \pm 2^{\mathrm{a}}$ & $94 \pm 2^{\mathrm{a}}$ & $95 \pm 2^{\mathrm{a}}$ \\
\hline P. harmala & $90 \pm 2^{\mathrm{a}}$ & $85 \pm 3^{a}$ & $61 \pm 4^{\mathrm{b}}$ & $50 \pm 5^{\mathrm{b}}$ & $90 \pm 2^{\mathrm{a}}$ & $83 \pm 3^{a}$ & $62 \pm 4^{b}$ & $45 \pm 4^{b}$ \\
\hline S. vermiculata & $71 \pm 4^{b}$ & $49 \pm 4^{c}$ & $82 \pm 3^{a}$ & $64 \pm 4^{b}$ & $67 \pm 4^{b}$ & $64 \pm 4^{b}$ & $78 \pm 3^{b}$ & $76 \pm 3^{b}$ \\
\hline \multicolumn{9}{|l|}{ Group II } \\
\hline G. capillaris & $4 \pm 1^{\mathrm{b}}$ & $0^{\mathrm{b}}$ & $4 \pm 1^{\mathrm{b}}$ & $0^{\mathrm{b}}$ & $42 \pm 4^{\mathrm{a}}$ & $37 \pm 4^{\mathrm{a}}$ & $42 \pm 4^{a}$ & $38 \pm 4^{a}$ \\
\hline H. dicksoniae & $15 \pm 3^{b}$ & $12 \pm 2^{\mathrm{b}}$ & $28 \pm 4^{\mathrm{ab}}$ & $24 \pm 3^{\mathrm{ab}}$ & $62 \pm 4^{\mathrm{a}}$ & $57 \pm 4^{\mathrm{a}}$ & $17 \pm 3^{b}$ & $15 \pm 3^{\mathrm{b}}$ \\
\hline H. lippi & $21 \pm 3^{c}$ & $6 \pm 1^{\mathrm{d}}$ & $28 \pm 4^{c}$ & $9 \pm 2^{\mathrm{d}}$ & $88 \pm 2^{\mathrm{a}}$ & $64 \pm 4^{\mathrm{b}}$ & $84 \pm 3^{\mathrm{a}}$ & $56 \pm 4^{\mathrm{b}}$ \\
\hline H. tuberculatum & $7 \pm 2^{\mathrm{c}}$ & $5 \pm 2^{c}$ & $4 \pm 2^{c}$ & $3 \pm 1^{\mathrm{c}}$ & $18 \pm 3^{b}$ & $14 \pm 3^{b}$ & $45 \pm 4^{\mathrm{a}}$ & $38 \pm 4^{\mathrm{a}}$ \\
\hline M. ciliata & $5 \pm 2^{b}$ & $6 \pm 2^{b}$ & $10 \pm 2^{\mathrm{b}}$ & $12 \pm 3^{b}$ & $29 \pm 4^{\mathrm{a}}$ & $31 \pm 4^{\mathrm{a}}$ & $13 \pm 3^{b}$ & $14 \pm 3^{\mathrm{b}}$ \\
\hline M. parviflora & $4 \pm 2^{\mathrm{a}}$ & $5 \pm 2^{\mathrm{a}}$ & $3 \pm 1^{\mathrm{a}}$ & $4 \pm 2^{\mathrm{a}}$ & $12 \pm 3^{a}$ & $12 \pm 3^{a}$ & $9 \pm 2^{\mathrm{a}}$ & $8 \pm 2^{\mathrm{a}}$ \\
\hline R. vesicarius & $29 \pm 4^{b}$ & $10 \pm 2^{\mathrm{d}}$ & $12 \pm 2^{\mathrm{d}}$ & $3 \pm 1^{\mathrm{e}}$ & $57 \pm 4^{\mathrm{a}}$ & $26 \pm 3^{c}$ & $31 \pm 4^{b}$ & $10 \pm 2^{\mathrm{d}}$ \\
\hline \multicolumn{9}{|l|}{ Group III } \\
\hline R. arabica & 0 & 0 & 0 & 0 & 0 & 0 & 0 & 0 \\
\hline \multicolumn{9}{|l|}{ Group IV } \\
\hline A. tenuifolius & $0^{\mathrm{a}}$ & $0^{\mathrm{a}}$ & $0^{\mathrm{a}}$ & $0^{\mathrm{a}}$ & $0^{\mathrm{a}}$ & $0^{\mathrm{a}}$ & $7 \pm 2^{\mathrm{a}}$ & $3 \pm 2^{\mathrm{a}}$ \\
\hline D. sanguinalis & $0^{\mathrm{b}}$ & $0^{\mathrm{b}}$ & $0^{\mathrm{b}}$ & $0^{\mathrm{b}}$ & $1 \pm 1^{\mathrm{b}}$ & $1 \pm 1^{\mathrm{b}}$ & $15 \pm 3^{\mathrm{a}}$ & $9 \pm 3^{\mathrm{a}}$ \\
\hline E. barrelieri & $0^{\mathrm{a}}$ & $0^{\mathrm{a}}$ & $0^{\mathrm{a}}$ & $0^{\mathrm{a}}$ & $1 \pm 1^{\mathrm{a}}$ & $3 \pm 2^{\mathrm{a}}$ & $1 \pm 1^{\mathrm{a}}$ & $1 \pm 1^{\mathrm{a}}$ \\
\hline S. parviflora & $0^{\mathrm{a}}$ & $0^{\mathrm{a}}$ & $0^{\mathrm{a}}$ & $0^{\mathrm{a}}$ & $9 \pm 3^{\mathrm{a}}$ & $8 \pm 3^{\mathrm{a}}$ & $0^{\mathrm{a}}$ & $0^{\mathrm{a}}$ \\
\hline \multicolumn{9}{|l|}{ Group V } \\
\hline C. arvensis & $0^{c}$ & $0^{\text {c }}$ & $0^{\mathrm{c}}$ & $0^{\mathrm{c}}$ & $53 \pm 0^{\mathrm{a}}$ & $40 \pm 5^{\mathrm{a}}$ & $9 \pm 2^{b}$ & $6 \pm 2^{b}$ \\
\hline B. tournefortii & $0^{\mathrm{b}}$ & $0^{\mathrm{b}}$ & $0^{\mathrm{b}}$ & $0^{\mathrm{b}}$ & $5 \pm 0^{\mathrm{b}}$ & $31 \pm 4^{\mathrm{a}}$ & $4 \pm 1^{b}$ & $28 \pm 4^{\mathrm{a}}$ \\
\hline E. curvula & $0^{\text {c }}$ & $0^{\text {c }}$ & $0^{c}$ & $0^{c}$ & $18 \pm 0^{\mathrm{b}}$ & $51 \pm 5^{\mathrm{a}}$ & $1 \pm 1^{\mathrm{c}}$ & $7 \pm 2^{b}$ \\
\hline P. monspeliensi: & $0^{\mathrm{b}}$ & $0^{\mathrm{b}}$ & $0^{\mathrm{b}}$ & $0^{\mathrm{b}}$ & $88 \pm 0^{\mathrm{a}}$ & $78 \pm 4^{\mathrm{a}}$ & $82 \pm 3^{\mathrm{a}}$ & $69 \pm 4^{\mathrm{a}}$ \\
\hline S. arabica & $0^{c}$ & $0^{c}$ & $0^{c}$ & $0^{c}$ & $75 \pm 0^{\mathrm{a}}$ & $72 \pm 4^{\mathrm{a}}$ & $26 \pm 4^{b}$ & $22 \pm 4^{b}$ \\
\hline S. villosa & $1 \pm 1^{\mathrm{c}}$ & $0^{\mathrm{c}}$ & $1 \pm 1^{\mathrm{c}}$ & $0^{\mathrm{c}}$ & $75 \pm 0^{\mathrm{a}}$ & $67 \pm 4^{\mathrm{a}}$ & $23 \pm 4^{\mathrm{b}}$ & $17 \pm 3^{b}$ \\
\hline
\end{tabular}

Note: Different lowercase letters within the same column indicate significances in germination percentages among different species at $P<0.05$ level. Mean \pm SE.

\section{Discussion and conclusions}

Seed germination in 13 of the 21 studied species was significantly increased by in situ storage. Stored seeds exhibited a thermoperiod response in germination. Conversely, fresh seeds exhibited a greater germination percentage under light, while stored seeds were only minimally affected. No phylogenetic correlation could be identified by the study, indicating that selection pressure for germination strategy is stronger than for taxonomic traits.

Understanding the mechanism for regulating dormancy provides insight into the ecological adaptation and regeneration of plants in natural environments. Most species in the Arabian Desert disperse their seeds just before the onset of summer (Capon and van Asdall, 1967; Gutterman, 2012), and thus being exposed to heat and moisture stresses. In the present study, only 4 of the 21 
species exhibited germinability and dispersal in March 2017. For 11 species, fresh seeds remained dormant and 5 species exhibited less than 10\% seed germination. An innate physiological dormancy has been previously reported for D. sanguinalis, E. curvula and S. villosa (Voigt and Tischler, 1997; Gallart et al., 2008; El-Keblawy and Gairola, 2017), but previous reports for $A$. tenuifolius, C. arvensis, D. tenuifolia and M. parviflora indicated no seed dormancy (Ruiz de

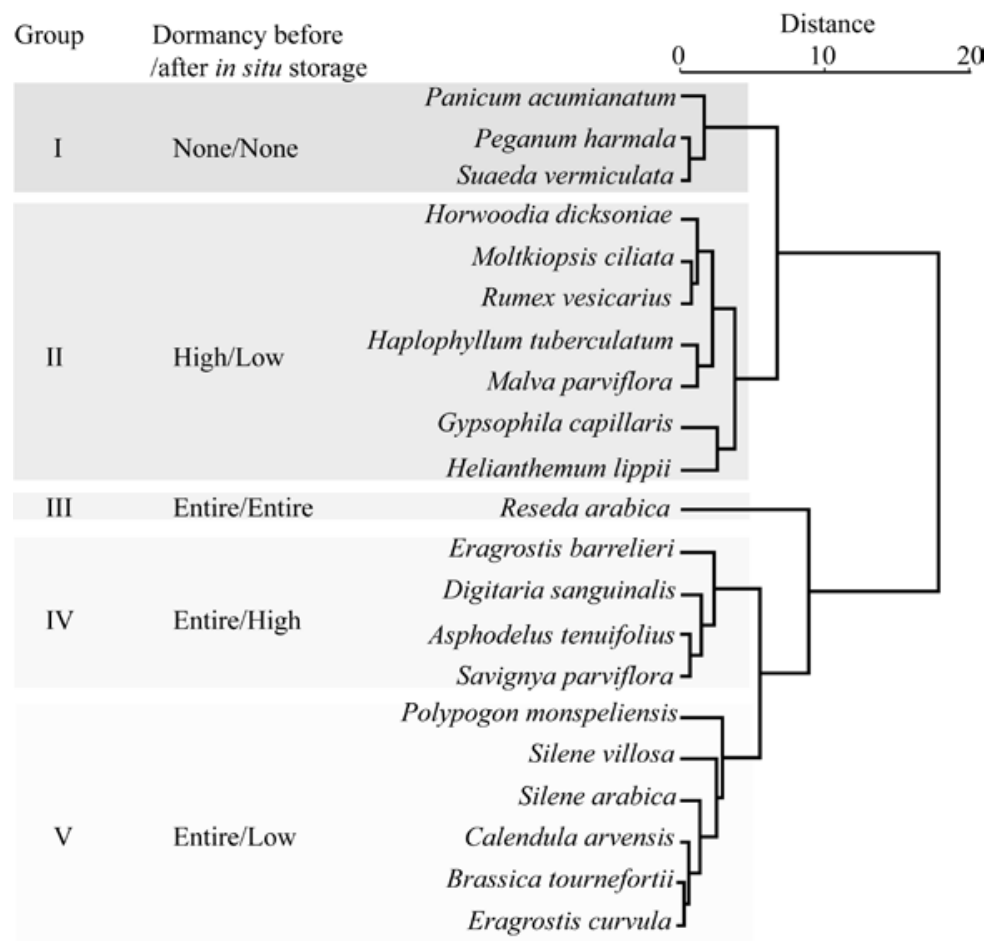

Fig. 1 Classification of species using clustering of seed germination under different seed storage (fresh and in situ stored seeds) and germination conditions of light (12 and $0 \mathrm{~h}$ per day) and temperature $\left(15^{\circ} \mathrm{C} / 20^{\circ} \mathrm{C}\right.$ and $\left.20^{\circ} \mathrm{C} / 30^{\circ} \mathrm{C}\right)$

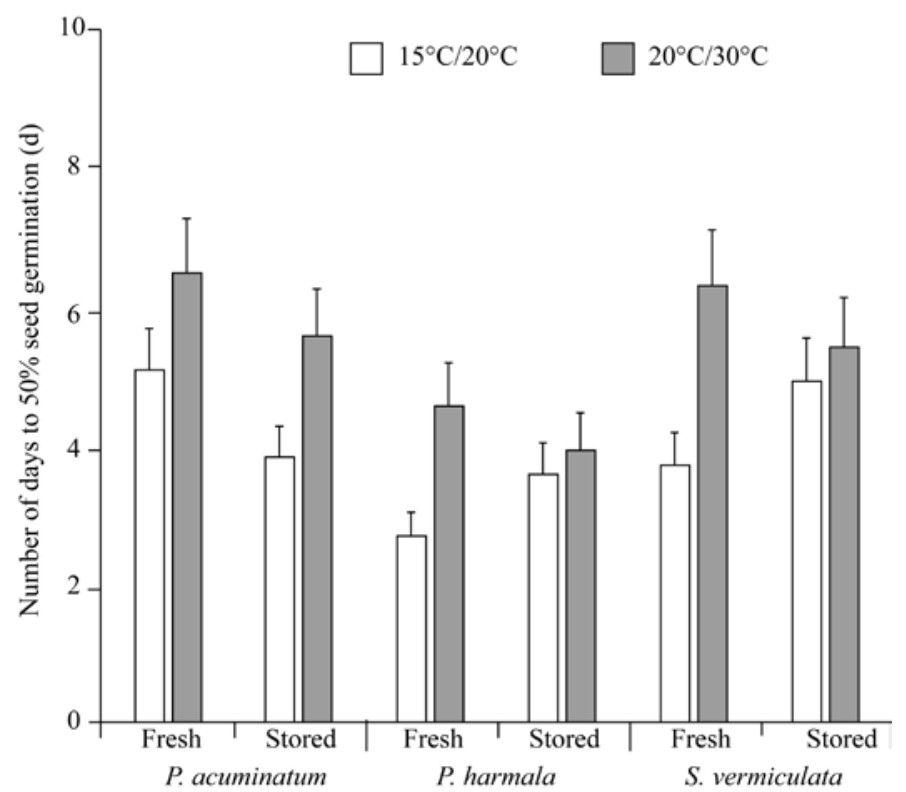

Fig. 2 Number of days to $50 \%$ germination of fresh and in situ stored seeds under $15^{\circ} \mathrm{C} / 20^{\circ} \mathrm{C}$ and $20^{\circ} \mathrm{C} / 30^{\circ} \mathrm{C}$ temperatures 


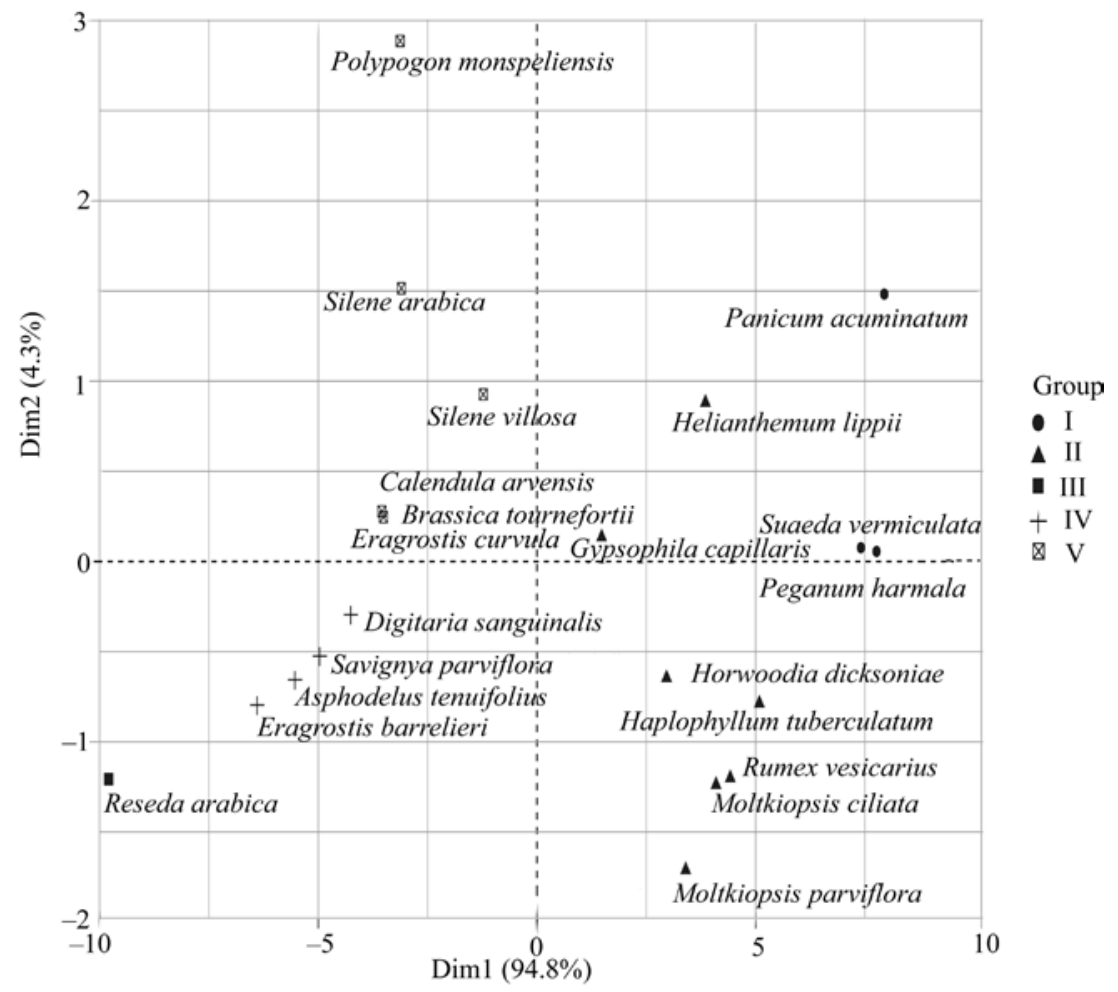

Fig. 3 Principal component analysis (PCA) of germination parameters of the species under different seed storage (fresh and in situ stored seeds) and germination conditions of light (12 and $0 \mathrm{~h}$ per day) and temperature $\left(15^{\circ} \mathrm{C} / 20^{\circ} \mathrm{C}\right.$ and $\left.20^{\circ} \mathrm{C} / 30^{\circ} \mathrm{C}\right)$. Group results of plant species can be found in Figure 1.

Clavijo, 2005; Khan et al., 2006; Michael et al., 2006; Sakcali and Serin, 2009). These differing observations may be related to environmental conditions at the maternal location. Seed germination of E. barrelieri and P. monspeliensis presented no dormancy, and the behavior could be attributed to after-ripening (Atia et al., 2011; El-Keblawy, 2017). Germination of fresh seeds was present but low (10\%-20\%) for three species, indicating a cautious germination strategy (Gutterman, 2002; Bhatt et al., 2016a). However, germination of 3 species was high (>50\%), indicating a readiness to germinate throughout the year if water is available. This opportunistic germination strategy has been reported for some other desert species (Gutterman, 2002; Bhatt et al., 2016d, e; El-Keblawy, 2017; Bhatt and Santo, 2018). All the 3 species are perennial and thus produce multiple batches of seeds within a life cycle, hence there is less risk to the population of a failed germination season. Germination behavior of species is normally correlated with the climatic conditions of the species origin (Baskin and Baskin, 2014). However, plant life cycle has played an important role in determining germination behavior of arid desert species (Schütz and Milberg, 1997), as found in the present case.

Germination percentages for 13 species significantly enhanced by in situ storage for groups II, IV and V. These desert species exhibit physiological dormancy and thus require a stimulus to trigger germination, along with $80 \%$ of all desert species. Almost all species in groups IV and V were annuals, but group II contained a mix of annuals and perennials. The storage in dry conditions at room temperature has been effective in alleviating physiological dormancy (Baskin and Baskin, 2004; Holdsworth et al., 2008). Most species in the current study have seeds with physiological dormancy at their maturity. Field conditions can enhance the after-ripening process and thus facilitate a higher germination when environmental conditions become favorable. Previous studies also concluded that field temperatures alleviated dormancy (Murdoch and Ellis, 2000; Adondakis and Venable, 2004; Commander et al., 2009). In the present study, R. arabica (group III) was alone in having no germinated seed after in situ storage, despite $92 \%$ seed 
viability at the end of the trial. This indicates that seeds might have deep physiological dormancy (Baskin and Baskin, 2004) that requires a longer period of after-ripening or different environmental conditions to alleviate.

For group I, the final germination was unaffected by storage, but time to germination was reduced, suggesting that seeds might be more ready to germinate under marginally favourable conditions. Seeds became responsive to the thermal conditions after dormancy alleviation. This result is at least partially attributable to the low germination of fresh seeds. On the basis of temperature response for germination of the in situ stored seeds, we can categorize the study species into 3 groups in which: (a) germination is promoted by the cooler temperature of $15^{\circ} \mathrm{C} / 20^{\circ} \mathrm{C}$ (C. arvensis, E. curvula, $H$. dicksoniae, M. ciliata, P. harmala, $R$. vesicarius, $S$. arabica, $S$. parviflora and $S$. villosa); (b) germination is promoted by the higher temperature of $20^{\circ} \mathrm{C} / 30^{\circ} \mathrm{C}(D$. sanguinalis and $H$. tuberculatum); and (c) germination is temperature-independent (P. acuminatum, S. vermiculata, G. capillaris, H. lippi, M. parviflora, E. barrelieri, B. tournefortii and $P$. monspeliensis). Temperature requirements indicate a natural germination season of group (a) from late January to early March, and group (b) in late November or late March to April, and group (c) at any time.

Light responses of seeds during germination increase likelihood of germination in favorable conditions (Baskin and Baskin, 2014). Light was required for germination of fresh but not stored seeds. Two group II species: $H$. lippi and $R$. vesicarius, exhibited a higher germination percentage when exposed to light, indicating a requirement for non-burial (Pons, 2000). Similar results were obtained for other species in the Arabian Desert (El-Keblawy et al., 2013; Bhatt et al., 2016b). Two group IV species: B. tournefortii and E. curvula, exhibited a higher germination percentage under darkness, which may be a strategy to avoid the desert environment. Sixteen species ( $A$. tenuifolius, C. arvensis, D. sanguinalis, E. barrelieri, G. capillaris, $H$. dicksoniae, $H$. tuberculatum, M. parviflora, M. ciliata, P. acuminatum, P. harmala, P. monspeliensis, S. parviflora, S. arabica, S. vermiculata and $S$. villosa) were light stimuli independent. In sandy desert habitats, seed burial under sand is common after high winds. Neutral photoelasticity may be a response to this variable habitat (Lai et al., 2016), though seeds buried too deep may have difficulty to emerge after germination (Bhatt and Santo, 2018). Small seeds usually require light for germination since the seed contains fewer resources for pre-emergent seedling growth (Milberg et al., 2000; Pons, 2000), but in the present study only a few species reflected this pattern.

Seed storage resulted in reduced germination time for $P$. acuminatum, $P$. harmala and $S$. vermiculata. Germination timing is usually correlated with dormancy alleviation (McIvor and Howden, 2000; Silva and Fernandes, 2014). Low germination timing may represent a desert adaptive strategy, where germination occurs rapidly after a rainfall event (Rühl et al., 2016).

Germination traits exhibited no correlation to phylogenetic signal, indicating that environmental selection is more important. As an example, seed behavior of E. barrelieri was distinct from E. curvula, despite being from the same genus. Wang et al. (2009) observed that germination patterns were similar among the plants from the same environment conditions rather than their phylogenetic relations. Also, some specific plant traits may be linked to the seed germination behavior in response to the environmental pressure as reported by Liu et al. (2018). We expect that under harsh environmental pressures of the desert, evolutionary pressure causes plant species to present specific germination behavior despite phylogenetic relationship. Further analysis is needed to verify if environmental features could explain the germination behavior patterns found in this work.

This study has enabled a better understanding of dormancy release and germination for the desert species under field conditions. Seed storage in situ for most studied species can increase the germination percentage and reduce time to germination. This confirms that most tested species have dormancy when seeds are fresh, which can be released under environmental cues that rain events occurs. We did not find any relationship of the germination behavior to the phylogenetic relation among the studied species. 


\section{Acknowledgements}

This work was supported by the Kuwait Institute for Scientific Research (KISR), Kuwait.

\section{References}

Adondakis S, Venable D L. 2004. Dormancy and germination in a guild of Sonoran Desert annuals. Ecology, 85(9): 2582-2590.

Almazroui M, Islam N M, Athar H, et al. 2012. Recent climate change in the Arabian Peninsula: annual rainfall and temperature analysis of Saudi Arabia for 1978-2009. International Journal of Climatology, 32(6): 953-966.

Atia A, Smaoui, A, Barhoumi Z, et al. 2011. Differential response to salinity and water deficit stress in Polypogon monspeliensis (L.) Desf. provenances during germination. Plant Biology, 13(3): 541-545.

Baker K S, Steadman K J, Plummer J A, et al. 2005 The changing window of conditions that promotes germination of two fire ephemerals, Actinotus leucocephalus (Apiaceae) and Tersonia cyathiflora (Gyrostemonaceae). Annals of Botany, 96(7): 1225-1236.

Barua D, Butler C, Tisdale T E, et al. 2012. Natural variation in germination responses of Arabidopsis to seasonal cues and their associated physiological mechanisms. Annals of Botany, 109(1): 209-226.

Baskin C C, Baskin J M. 2014. Seeds: Ecology, Biogeography, and Evolution of Dormancy and Germination (2 ${ }^{\text {nd }}$ ed.). San Diego: Academic Press, 666.

Baskin J M, Baskin C C. 1988. Role of temperature in regulating the timing of germination in Portulaca oleracea. Canadian Journal of Botany, 66: 563-567.

Baskin J M, Baskin C C. 2004. A classification system for seed dormancy. Seed Science Research, 14(1): 1-16.

Bates D, Mullen K M, Nash J C, et al. 2014. Minqa: Derivative-Free Optimization Algorithms by Quadratic Approximation. R package version 1.2.4. [2020-02-10]. http://CRAN. R-project.org/package=minqa.

Bhatt A, Carón M M, Verheyen K, et al. 2016a. Germination and seedling performance of five native legumes of the Arabian Desert. Flora, 220: 125-133.

Bhatt A, Pérez-García F, Phondani P C. 2016b. Foliage colour influence on seed germination of Bienertia cycloptera in Arabian Desert. Nordic Journal of Botany, 34(4): 428-434.

Bhatt A, Phondani P C, Phartyal S S, et al. 2016c. Influence of aerial seed banks on germination response in three desert plant species. Journal of Plant Ecology, 10(6): 994-1000.

Bhatt A, Pérez-García F, Mercedes Carón M, et al. 2016d. Germination response of Salsola schweinfurthii (Chenopodiaceae) to salinity and winged perianth removal. Seed Science and Technology, 44(2): 428-434.

Bhatt A, Gairola S, El-Keblawy A. 2016e. Seed colour affects dormancy and germination requirements in two species of Lotus (Fabaceae). Revista de Biologia Tropical, 64: 483-492.

Bhatt A, Pérez-García F. 2016. Seed dormancy of Ochradenus baccatus (Resedaceae), a shrubby species from Arabian desert regions. Revista de Biologia Tropical, 64: 965-974.

Bhatt A, Santo A. 2017. Effects of photoperiod, thermoperiod, and salt stress on Gymnocarpos decandrus seeds: potential implications in restoration ecology activities. Botany, 95(11): 1093-1098.

Bhatt A, Santo A. 2018. Different ecological strategies during the seed germination phase of nine grasses inhabiting the hyper-arid Arabian Desert. Plant Species Biology, 33(4): 305-311.

Böer B. 1997. An introduction to the climate of the United Arab Emirates. Journal of Arid Environments, 35(1): 3-16.

Burns J H, Strauss S Y. 2011. More closely related species are more ecologically similar in an experimental test. Proceedings of the National Academy of Sciences of the United States of America, 108(13): 5302-5307.

Capon B, van Asdall W. 1967. Heat pre-treatment as a means of increasing germination of desert annual seeds. Ecology, 48(2): 305-306.

Carta A, Probert R J, Moretti M, et al. 2014. Seed dormancy and germination in three Crocus ser. verni species (Iridaceae): implications for evolution of dormancy within the genus. Plant Biology, 16(6): 1065-1074.

Clauss M J, Venable D L. 2000. Seed germination in desert annuals: an empirical test of adaptive bet hedging. The American Naturalist, 155(2): 168-186.

Commander L E, Merritt D J, Rokich D P, et al. 2009. The role of after-ripening in promoting germination of arid zone seeds: a study on six Australian species. Botanical Journal of the Linnean Society, 161(4): 411-421.

de Clavijo E R. 2005. The reproductive strategies of the heterocarpic annual Calendula arvensis (Asteraceae). Acta Oecologica, 28(2): 119-126.

Délye C M, Jasieniuk V, Le Corre V. 2013. Deciphering the evolution of herbicide resistance in weeds. Trends in Genetics, 
29(11): 649-658.

Donohue K. 2002. Germination timing influences natural selection on life-history characters in Arabidopsis thaliana. Ecology, 83(4): 1006-1016.

Donohue K, Rubio de Casas R, Burghardt L, et al. 2010. Germination, postgermination adaptation, and species ecological ranges. Annual Review of Ecology, Evolution, and Systematics, 41: 293-319.

El-Keblawy A, Al Neyadi S S, Rao M V, et al. 2011. Interactive effects of salinity, light and temperature on seed germination of sand dunes glycophyte Cyprus conglomeratus growing in the United Arab Emirates deserts. Seed Science and Technology, 39(2): $364-376$.

El-Keblawy A, Bhatt A, Gairola S. 2013. Perianth colour affects germination behaviour in wind-pollinated Salsola rubescens in Arabian deserts. Botany, 92(1): 69-75.

El-Keblawy A. 2017. Light and temperature requirements during germination of potential perennial grasses for rehabilitation of degraded sandy Arabian deserts. Land Degradation \& Development, 28(5): 1687-1695.

El-Keblawy A, Gairola S. 2017. Dormancy regulating chemicals alleviate innate seed dormancy and promote germination of desert annuals. Journal of Plant Growth Regulation, 36: 300-311.

Erickson T E. 2015. Seed dormancy and germination traits of 89 arid zone species targeted for mine-site restoration in the Pilbara region of Western Australia. Ph. Dissertation. Perth: University of Western Australia.

Evans A S, Cabin R J. 1995. Can dormancy affect the evolution of post-germination traits? The case of Lesquerella fendleri. Ecology, 76(2): 344-356.

Fenner M, Thompson K. 2005. The Ecology of Seeds. Cambridge: Cambridge University Press, 250.

Finch-Savage W E, Leubner-Metzger G. 2006. Seed dormancy and the control of germination. New Phytologist, 171(3): 501-523.

Gallart M, Verdú A M C, Mas M T. 2008. Dormancy breaking in Digitaria sanguinalis seeds: the role of the caryopsis covering structures. Seed Science and Technology, 36(2): 259-270.

Gutterman Y. 1972. Delayed Seed dispersal and rapid germination as survival mechanisms of the desert plant Blepharis persica (Burm.). Knntze. Oecologia, 10: 145-149.

Gutterman Y. 2002. Survival Strategies of Annual Desert Plants. Heidelberg: Springer, 348.

Gutterman Y. 2012. Seed Germination in Desert Plants. New York: Springer Science \& Business Media, 253.

Harel D, Holzapfel C, Sternberg M. 2011. Seed mass and dormancy of annual plant populations and communities decreases with aridity and rainfall predictability. Basic and Applied Ecology, 12(8): 674-684.

Holdsworth M J, Bentsink L, Soppe W J J. 2008. Molecular networks regulating Arabidopsis seed maturation, after-ripening, dormancy and germination. New Phytologist, 179(1): 33-54.

Hothorn T, Bretz F, Westfall P. 2008. Simultaneous inference in general parametric models. Journal of Mathematical Methods in Biosciences, 50(3): 346-363.

Jombart T, Dray S. 2008. Adephylo: Exploratory analyses for the phylogenetic comparative method. Bioinformatics, 26: 1907-1909.

Jordan G L, Haferkamp M R. 1989. Temperature responses and calculated heat units for germination of several range grasses and shrubs. Rangeland Ecology \& Management, 42(1): 41-45.

Khan M I, Hassan G, Khan I, et al. 2006. Germination of Asphodelus tenuifolius biotypes as influenced by temperature, dormancy breaking chemicals and their concentrations. Pakistan Journal of Weed Science Research, 12: 313-318.

Lai L M, Chen L J, Jiang L H, et al. 2016. Seed germination of seven desert plants and implications for vegetation restoration. AoB Plants, 8: plw031.

Lenth R V. 2016. Least-squares means: the R package lsmeans. Journal of Statistical Software, 69: 1-33.

Liu K, Cao S, Du G, et al. 2018. Linking seed germination and plant height: a case study of a wetland community on the eastern Tibet Plateau. Plant Biology, 30: 886-893.

Liu S Z, Liu Y J, Ji Y F, et al. 2013. Seed germination of Corispermum patelliforme in different storage length at room temperature: a dominant annual plant species in the deserts of northern China. Pakistan Journal of Botany, 45: 737-742.

McIvor J G, Howden S M. 2000. Dormancy and germination characteristics of herbaceous species in the seasonally dry tropics of northern Australia. Austral Ecology, 25: 213-222.

Menon K, Jayakumar A P, Shahid M, et al. 2014. Seed dormancy and effect of salinity on germination of Citrullus colocynthis. International Journal of Environmental Science and Development, 5: 566.

Michael P J, Steadman K J, Plummer J A. 2006. Climatic regulation of seed dormancy and emergence of diverse Malva parviflora populations from a Mediterranean-type environment. Seed Science Research, 16(4): 273-281.

Milberg P, Andersson L, Thompson K. 2000. Large-seeded spices are less dependent on light for germination than small-seeded 
ones. Seed Science Research, 10(1): 99-104.

Mira S, González-Benito M E, Ibars A M, et al. 2011. Dormancy release and seed ageing in the endangered species Silene diclinis. Biodiversity and Conservation, 20: 345-358.

Murdoch A J, Ellis R H. 2000. Dormancy, viability and longevity. In: Fenner M. Seeds: the Ecology of Regeneration in Plant Communities ( $2^{\text {nd }}$ ed.). Wallingford: CABI Publishing, 183-214.

Norton J, Abdul Majid S, Allan D, et al. 2009. An Illustrated Checklist of the Flora of Qatar. Gosport: Browndown Publications, 67.

Oksanen A J, Blanchet F G, Kindt R, et al. 2019. Vegan: Community Ecology Package. R package version 2.5-4. [2019-11-09]. https://cran.rproject.org/package=vegan.

Omar S A S, Al-Mutawa Y, Zaman S. 2007. Vegetation of Kuwait. Kuwait: Kuwait Institute for Scientific Research, 47-89.

Onofri A, Carbonell E A, Piepho H P, et al. 2010. Current statistical issues in weed research. Weed Research, 50(1): 5-24.

Petrie J M. 2007. Arabian desert primer: ornamental potential of hyper-arid adapted plants from Saudi Arabia. Desert Plants, 19-32.

Pons T L. 2000. Seed responses to light. In: Fenner M. Seeds-the Ecology of Regeneration in Plant Communities. New York: CABI Publishing, 237-260.

Revell L J. 2012. Phytools: An R package for phylogenetic comparative biology (and other things). Methods in Ecology and Evolution, 3(2): 217-223.

Rühl A T, Eckstein R L, Otte A, et al. 2016. Distinct germination response of endangered and common arable weeds to reduced water potential. Plant Biology, 18(S1): 83-90.

Ruiz de Clavijo E. 2005. The reproductive strategies of the heterocarpic annual Calendula arvensis (Asteraceae). Acta Oecologica, 28(2): 119-126.

Sakcali MS, Serin M. 2009. Seed germination behaviour of Diplotaxis tenuifolia. EurAsian Journal of BioSciences, 3: 107-112.

Schütz W, Milberg P. 1997. Seed germination in Launaea arborescens: a continuously flowering semi-desert shrub. Journal of Arid Environments, 36(6): 113-122.

Schütz W, Milberg P, Lamont B B. 2002. Seed dormancy, after-ripening and light requirements of four annual Asteraceae in southwestern Australia. Annals of Botany, 90: 707-714.

Seglias A E, Williams E, Bilge A, et al. 2018. Phylogeny and source climate impact seed dormancy and germination of restoration-relevant forb species. PLoS ONE, 13: e0191931, https://doi. org/10.1371/journal.pone.0191931.

Sileshi G W. 2012. A critique of current trends in the statistical analysis of seed germination and viability data. Seed Science Research, 22(3): 145-159.

Silva L M, Fernandes G W. 2014. Effect of seed storage on germination, seedling growth and survival of Mimosa foliolosa (Fabaceae): implications for seed banks and restoration ecology. Tropical Ecology, 55(3): 385-392.

Terradas J. 1991. Mediterranean woody plant growth-forms, biomass and production in the eastern part of the Iberian Peninsula. In: Ros J D, Prat N. Hom-age to Ramon Margalef or Why Is There Such Pleasure in Studying Nature (Oecologia aquatica; 10), Barcelona: University of Barcelona, 337-349.

Therneau T M, Grambsch P M. 2000. Modeling Survival Data: Extending the Cox Model. New York, Springer. [2019-11-02]. https://doi. org/10.1007/978-1-4757-3294-8.

Tudela-Isanta M, Ladouceur E, Wijayasinghe M, et al. 2018. The seed germination niche limits the distribution of some plant species in calcareous or siliceous alpine bedrocks. Alpine Botany, 128: 83-95.

Voigt P W, Tischler C R. 1997. Effect of seed treatment on germination and emergence of 3 warm-season grasses. Rangeland Ecology \& Management, 50(2): 170-174.

Wang J H, Baskin C C, Cui X L, et al. 2009. Effects of phylogeny, life history and habitat correlates on seed germination of 69 arid and semi-arid zone species from Northwest China. Evolutionary Ecology, 23: 827-846.

Webb C O, Donoghue M J. 2005. Phylomatic: Tree assembly for applied phylogenetics. Molecular Ecology Notes, 5(1): 181-183.

Zanne A E, Tank D C, Cornwell W K, et al. 2014. Three keys to the radiation of angiosperms into freezing environments. Nature, 506: 89-92.

Zhang L W, Liu H L, Zhang D Y, et al. 2015. Seed dormancy release and germination characteristics of Corispermum lehmannianum Bunge, an endemic species in the Gurbantunggut Desert of China. Phyton, 84(1): 58-63.

Zuur A, Elena N I, Walker N, et al. 2009. Mixed Effects Models and Extensions in Ecology with R. New York: Springer Science \& Business Media, 579. 